\title{
Adopting a value co-creation perspective to understand High Street regeneration
}

\author{
Authors \\ Kim Cassidy (Edgehill University UK) Contact Kim.cassidy@edgehill.ac.uk \\ Sheilagh Resnick (Nottingham Trent University UK) Contact Sheilagh.Resnick@ntu.ac.uk
}

\begin{abstract}
The 'High Street' has traditionally played a key role in the health of towns worldwide. It is instrumental as a community hub, supporting local independent retail businesses and incubating entrepreneurship and innovation. Since 2009, thousands of stores have closed with record levels of shop vacancies. Reasons for the decline include a failure to respond to multi-channel retailing, wider demographic and economic changes and problems coordinating the network of actors who hold competing ideas about High Street regeneration. This paper evaluates the contribution of a value co-creation perspective in exploring strategy making in a complex retail high street ecosystem. It draws on Service-Dominant Logic and its service ecosystems perspective, institutional theory and data from a depth case study of strategy development in a UK High Street. The study illustrates how the value co-creation perspective, underpinned by institutional theory offers a rich appreciation of how actors in the ecosystem participate in shaping strategy. It identifies seven norms shared by the multiple actors, which serve as a point of reference for more sustainable strategy development. The normative analysis highlights the potential of operant resources amongst actors to shape strategy implementation. The study provides empirical evidence to support the role of institutions and institutional arrangements in effective value co-creation.
\end{abstract}

Key Words: Service-Dominant Logic, ecosystem, operant resources, value creation, norms, institutions, UK High Street. 


\section{Introduction}

Retail high streets have traditionally played a crucial role in the economic and social health of towns and cities worldwide but since 2009 , have been decimated by the closure of tens of thousands of retail stores across the United States and Europe. The performance of the UK High Street is one of decline. Footfall in town centres has decreased every year since 2013 and in the last 10 years, has fallen by $17 \%$ (Grimsey, 2018, p.16). In the first six months of 2018 , the number of premises lying empty in town centres in the UK soared by more than 4,400 (Local Data Company, 2018) with the closure of 24 stores resulting in over 20,000 job losses (Centre for Retail Research, 2018). Factors contributing to this decline include the increase in online shopping, the impact of competition from out-of-town 'one stop' retail developments and the rise of a convenience culture, which reflects a shift in consumer behaviour and the desire to offset convenience of location against cost (Wrigley \& Limber, 2015). 'Other new and unforeseen factors like Brexit have exacerbated problems with a weaker pound and the subsequent pressure on retail prices' (Grimsey, 2018, p.4). Despite this generally pessimistic outlook, the Grimsey Review highlights examples of best practice, which illustrate how some towns are fighting back, rethinking their retail offer and benefiting from effective collaboration or value co-creation efforts of key institutional actors. 'Strong local leadership appears to be working hard to create a balanced high street ecosystem with a unique identity' (Grimsey, 2018, p.11). At the heart of many of these success stories lies a strong strategic plan, which takes account of the myriad of macro and micro environmental challenges facing the sector and strives to reinforce a distinctive positioning for the town.

The concept of value co-creation had become firmly established in the marketing literature (Galvagno \& Dalli, 2014; Ramaswamy \& Ozcan, 2014) and is a fundamental construct within Service-Dominant Logic (S-D) Logic (Vargo \& Lush, 2004; 2008; 2011). It typically explains the move from regarding organisations as a definer of value to a process whereby people and organisations jointly develop meaning and outcomes (Alves, Fernandes \& Raposo, 2016). A SD Logic value co-creation perspective would view the High Street as a 'service ecosystem', a 'relatively self-contained, self-adjusting system of resource-integrating actors connected by shared institutional arrangements and mutual value creation through service exchange' (Vargo \& Lusch 2016, pp.11-12). The ecosystem perspective places emphasis on institutions i.e. the norms, rules, values, meanings, symbols and practices, which the connected actors 
share (Scott, 2008) and also takes account of the many interactions amongst and between multiple actors within the system. According to Vargo \& Lusch (2016), value co-creation is coordinated through actor-generated institutions and institutional arrangements. This theoretical perspective, when applied to service ecosystems, has already shown to provide a direction for enhancing the understanding of service ecosystem actors and their interactions (Baron et al., 2018, p.136). The notion of resource integration is also fundamental within a SD Logic, value co-creation perspective. Actors within the ecosystem integrate operant resources (such as human skills and knowledge) and operand resources (physical assets) to co-create value (Vargo \& Lusch, 2004).

The aim of this study is to understand the role and value of a value co-creation perspective in assessing regeneration activities in a UK retail high street 'service ecosystem'. Our focus here stems not only from the fact that retail (as a service) remains significant as a sub discipline of marketing, occupying a large portion of the extant marketing literature (Finnegan et al., 2016) but the future of the High Street appears to be at crucial turning point. Like many other areas of retailing, it is experiencing an unprecedented period of change, not only in the nature of the offer and the environment in which it exists, but also in the actors who participate and their respective roles (Collin-Lachaud \& Reynolds, 2018; Hagberg, Sundstrom \& Egels-Zandén, 2016).

There is a pressing need to better understand the complex and often conflicting needs and priorities of the myriad of actors charged with regeneration activities. Underpinned by an institutional theory perspective, this study uncovers the norms shared by multiple actors in the high street ecosystem involved in successful value co-creation. The research uses a case study to highlight actors' perceptions of actions required to develop strategy in a UK high street context. The case study accesses the views of multiple actors within the ecosystem, comparing voices of consumers, businesses and public and private service providers to 'compare different empirical settings in order to provide more effective results' (Galvagno \& Dalli, 2014, p. 658). The context for our study, a UK town, faced challenges of declining footfall and increased shop vacancies, and involved a range of actors in an extensive process of consultation to shape a future for the High Street. 
The main contribution of the study lies in providing empirical evidence to illustrate the value of adopting a value co-creation perspective, underpinned by institutional theory, to understand and shape strategy making in a High Street ecosystem. The study identifies the dynamics of collaboration and actor generated institutions in the ecosystem. First, the research identified seven norms, which appear to be sustaining institutional arrangements. These norms reflect agreement about equity and fairness, balance of provision, access, best practice, a sustainable, healthy environment, the need for a point of difference and standards and professionalism. The norms shared by the multiple actors, serve as a point of reference for the development of a more sustainable, strategy moving forward. Second, the normative analysis offers insights about resource integration practices. The findings draw attention to the existence of operant resources amongst actors, which if harnessed effectively, could potentially contribute to strategy implementation in the High Street context. The value cocreation perspective offers a welcome departure from the more traditional marketing approaches. These tend to characterise value creation as linear and sequential and fail to capture any depth of understanding of the 'highly intertwined nature of market and value cocreation practices and how these practices change through the interplay with each other' (Wieland, Koskela-Huotari \& Vargo, 2016, p. 220).

The article is structured as follows: First, a literature review synthesises research exploring the nature and contribution of an S-D Logic perspective on value co-creation and its service ecosystems perspective. Given the role of institutions and institutional arrangements in guiding value creation practices, our review also evaluates the contribution of institutional theory. The review also acknowledges resource integration processes in knowledge cocreation. Second, the article presents the empirical setting and method for the study, a high street ecosystem. It illustrates the process of data collection and highlights the value of uncovering norms when analysing the data. Third, the article outlines the findings, the seven norms binding actors together in the High Street ecosystem and some of the operant resources at play within resource integration. A discussion section follows which reflects on how the findings relate to prior research. The final section of the article concludes by reinforcing the contribution and outlining the limitations of this study and avenues for further research. 


\section{Literature}

In their work on service-dominant (S-D) logic and service ecosystems, Vargo \& Lusch (2004; 2008; 2011) argue that value is co-created by multiple actors exchanging and integrating resources for the benefit of both the actors and the system. This view deviates from 'linear, sequential creation and flow perspectives of value toward the existence of more complex and dynamic exchange systems of actors (i.e. service ecosystems) in which value creation practices are guided by institutions (i.e. rules, norms, meanings, symbols, and similar aides to collaboration) and, more generally, institutional arrangements (i.e. interdependent sets of institutions)'(Wieland, Koskela-Huotari \& Vargo, 2016, p.211). In order to establish the theoretical underpinning for this research our review considers two streams of literature, SD Logic and its service ecosystems perspective, and institutional theory. This focus requires us to draw on two of the three strands of Gao, et al., (2010, p.380) strategy tripod to develop our understanding of strategy development. The dominant lens here is the institutional perspective, which acknowledges the importance of context and the impact of shared rules, norms and symbols on strategy development. However, given that 'S-D Logic's view on resources builds on and extends resource-based views of exchange and the firm' (KoskelaHuotari \& Vargo, 2016, p.66) the resource-based paradigm inevitably informs our discussion of resource integration.

S-D logic and the eco-system perspective

Value co-creation

Throughout the $20^{\text {th }}$ century, a preeminent view was that the production process and linear value chain represented the sole means by which value was created. The end of the century saw the emergence of the view that customers create value or rather co-create it (Wikström, 1996; Ramírez, 1999). A value co-creation perspective sees the customer as being a participant in the process of a service (Prahalad \& Ramaswamy, 2004; Gronroos, 2006) as it allows the customer to 'co-construct the service experience to suit their context' (Prahalad \& Ramaswamy, 2004, p. 8). It has been described as both a management initiative and an economic strategy that brings different parties together in order to jointly produce a mutually valued outcome. 'It urges marketing scholars and practitioners to abandon the producer and consumer divide and to see all parties as resource-integrating actors with the 
common goal of co-creating value for themselves and others' (Wieland, Koskela-Huotari \& Vargo 2016, p.212)

Since its inception, the notion of value co- creation has spawned a wide range of research in different settings. The contribution of the perspective has been evaluated in healthcare (McColl-Kennedy et al., 2012), e-commerce (Barrutia, Paredes \& Echebarria, 2016), sport (Horbel et al., 2016) and Fan Fests (Kolyperas \& Sparks, 2018). The underlying view of value co-creation is that of a process in which both customers and organisations contribute to create meaning (Ind \& Coates, 2013).

Within S-D Logic, value creation is viewed as a process that includes activities involving a service provider, such as an organisation, and a service recipient, the customer. Value cocreation is achieved through 'economic and social actors interacting and exchanging across and through networks' (Vargo \& Lusch, 2008, p. 5). Value co creation activities are likely to create a superior customer experience and can result in firms securing competitive advantage (Crick, Chaudhry \& Crick, 2016).

\section{Resources and resource integration}

The co-creation of value is the outcome of resource integration in the service system (Kleinaltenkamp et al., 2012). Central to S-D Logic is the notion of actors engaged in the exchange of operand and operant resources. Operand resources are generally physical and inanimate in nature, such as raw materials and land; operant resources are human activities, involving the application of skills, knowledge and competencies such as organisational and relational abilities (Hunt, 2004). In their study of individual customer's operant resources in the context of the UK British Library, Baron \& Warnaby (2011) offer empirical support for subdividing operant resources into physical, cultural and social (Arnould, Price \& Malshe, 2006). They describe this stock of operant resources as those over which the individual has 'authoritative' capability and illustrate how this classification provides rich insights into how to manage co-creation (Baron \& Warnaby, 2011, p.211). Using this classification, physical resources refer to the energy, emotion and strength of the actors. Social resources to family relationships, brand communities, consumer tribes and commercial relationships and cultural resources to specialized knowledge/skills, history and imagination.

'Although the primacy of operant resources is a central aspect of S-D Logic, it does not reduce the importance of operand resources (e.g. natural resources). Rather, it emphasizes the integration of skills to develop new knowledge (Lusch, Vargo \& Tanniru, 2010) to apply 
operand resources in a more effective, including efficient and sustainable, manner' (KoskelaHuotari \& Vargo 2016, p.166)

The focus on resources within S-D Logic aligns itself with the resource-based view (RBV) which argues that firms can derive competitive advantage from resources and/or capabilities (Barney, 1991) which can be tangible or intangible. However, as Koskela-Huotari \& Vargo, (2016) point out there is a 'notable difference with S-D Logic and many of the resource-based approaches' (p.166). Namely the emphasis of the former that resource application must benefit other actors. 'In other words, resources are applied and integrated to co-create value - that is, to improve the wellbeing of oneself by improving the wellbeing of others' (p.166). Insights from the resource-based view also draw a distinction between threshold capabilities (Johnson, Whittington \& Scholes, 2011) or ordinary capabilities (Teece, 2014) which enable firms and organisations to achieve parity with competitors in a given environment and dynamic capabilities, i.e. the ability to integrate and reconfigure capabilities to secure competitive advantage.

Within a High Street context it might be argued that many actors possess the skills and knowledge (operant resources) to improve public realm i.e. plant trees and create cycle pathways. As this has long been an expected part of the work of most high street managers, these resources contribute to threshold capabilities. Fewer will have actors with expertise in social media, capable of enhancing the digital profile and performance of the destination. Arguably, the latter contribute to the dynamic capabilities of the place and are likely to represent a source of differentiation for a specific town centre.

The notion of 'resourceness' is also fundamental within S-D logic and reinforces the contextual character of resource integration. This draws attention to the fact that resources themselves are not inherently "valuable," but become more or less valuable depending on the context of their integration (Chandler \& Vargo, 2011).

Service ecosystems

In their work on S-D Logic, Vargo \& Lusch $(2017$, p.4) argue that value co-creation is coordinated through actor generated institutions, with the service ecosystem acting as the unit of analysis. Ramaswarmy \& Ozcanb (2018, p.196) have recently developed this idea further to suggest that co -creation is a representation of 'interactional creation of interactive systemenvironments'. In this perspective, value co creation has moved away from a two way process 
to the notion of exchange amongst multiple actors within a service ecosystem (Wieland, Koskela-Huotari \& Vargo, 2016). According to Gummesson (2008) the service ecosystems perspective urges balanced centricity and a more generic actor conceptualisation (Lusch \& Vargo, 2014).

An ecosystem describes how actors interact, their mutual dependence, their activities and how they change within the system (Frow et al., 2014). It can be viewed as 'relatively selfcontained, self-adjusting system of resource-integrating actors connected by shared institutional arrangements and mutual value creation through service exchange' (Vargo \& Lusch, 2016, p.16). It is a perspective, which prioritises understanding the many interactions amongst and between multiple actors - as well as how resources are integrated, and the impact of social forces - at and between three inter-related levels: macro, meso and micro (Akaka \& Vargo 2015; Fisk et al., 2016; Witell et al., 2015). The macro level reflects shared networks and institutions; meso level represents firm and customer networks and institutions, and the micro level is the firm and customer interactions (Akaka \& Vargo, 2015, p. 213.).

A study of any ecosystem is challenging as they comprise numerous actors, considers social forces and require co-creation and resource integration activities (Akaka \& Vargo 2015). An increasing number of service scholars are beginning to adopt a service ecosystem perspective to address marketing issues in complex environments (see Frow et al., 2014; Fisk et al., 2016; Baron et al., 2018). Baron et al., (2018), for example, explored service innovation within the UK food waste ecosystem, using data from the actors 'to clarify the distinctions between institutions and highlight theoretical implications for service innovation' (p. 135). In an entirely different context, Damacena, Schmidt \& Gauze (2018) examined the ecosystem of a wedding to understand the social and cultural factors that create the system structure in this setting.

Within a service ecosystem, there lies value, which is offered, and value, which is sought by the different actors in the system (Frow et al., 2014). Although within the system, actors cocreate and share value, not all actors are treated equally. There are key actors, on whom the ecosystem depends. They provide resources without which other actors in the system would not be able to operate. However, the activities of resource integration are carried out by individuals and organizations, who often act according to their own interests, and who are not always in agreement with each other. It has been said that this may result in conflict, 
placing some actors in a position to negotiate a more favourable value exchange than others (Mars, Bronstein \& Lusch, 2012). In their review of the relevance of property rights theory, Haase \& Kleinaltenkamp, (2011), argue that collaborative processes need to be regulated or solved by the resource-integrating parties' joint efforts. Strategy development, therefore, needs to consider how best to balance the value co-created from each group so that the overall benefit can be achieved and sustained. Ecosystems typically have large numbers of actors who are continually sharing resources with each other. Because actors often hold differing views, service ecosystems may not survive if actors cannot adapt to changes in the system, or if actors cease to integrate effectively (Frow et al., 2014).

Institutions and institutional arrangements

An ecosystem perspective places emphasis on institutions and institutional arrangements i.e. the norms, rules, values, meanings, symbols and practices, which the connected actors share (Scott, 2008). These shared institutions and institutional arrangements, apply the glue for the working of a service ecosystem, and can only be discovered through detailed investigations of day-to-day activities of the actors (Baron et al., 2018). They offer a means of ensuring that ecosystems survive and bind actors together. In this way, value co-creation practices are shaped by enabling and constraining how actors integrate resources, conceptualize markets, and perceive value (Edvardsson et al., 2014; Lusch \& Vargo, 2014; Vargo, Wiseland \& Akaka, 2015).

Institutional theory itself originates from a range of theoretical foundations, such as sociology (Giddens, 1984), organizational studies (Scott, 2014) and economics (North, 1990; Nelson \& Sampat, 2001). According to Giddens (1984), institutions represent the more enduring features of social life as these humanly devised rules, norms, values, and beliefs make social life predictable and meaningful.

According to North's (1990, p.70) perspective, institutions as 'a set of rules governing interpersonal governance.' These rules may be of a regulative, normative, or cognitive nature (Scott, 2008) and are devised by humans. They emerge from practices derived in the resource integration process and prove to be effective in shaping and controlling human behaviour (Edvardsson, et al., 2014). In this context, institutions enable and at the same time constrain resource integration and value creation in service systems. They are configurations of actors, 
resources, and technology designed to enable value co-creation (Spohrer, Maglio, \& Bailey, 2007). As service systems are shaped by social values and forces in social systems (Edvardsson et al., 2014), institutional settings and thus institutional logics affect service systems and the involved actors' behavior. 'Institutional logics influence both how value cocreation in service systems comes about and the design and development of value propositions and the supporting service systems in action' (Evardsson et al., 2014, p.302).

In a recent review of institutional change in health care systems Pop et al., (2018 p.595) identified three insights from institutional theory that they felt were critical to our understanding of institutions in service eco-systems. Two positive and one negative. First, institutions provide information and signposts encouraging orderly behaviour with rules and scripts. Second, they can help to manage conflict. Third, they simplify rational thought with the risk that actors act without thinking and sometimes fail to challenge the status quo and innovate.

In a recent paper Wieland, Koskela-Huatari \& Vargo (2016), draw on the institutional perspective to consider how actor participation in value co-creation might be extended. They highlight the critical role actors play in institutional 'work' namely maintaining, creating and disrupting institutions (see also Nenonen, Gummerus, \& Sklyar, 2018). Wieland, KoskelaHuatari \& Vargo (2016) call for more research to understand how actors resolve 'contradictions and inconsistencies in the institutional arrangements that guide the enactment of both market and value co-creation practices and, thus, the ongoing emergence and decline of new problems and solutions' (p.221).

Based on insights from healthcare, Pop et al., (2018) developed a typology of institutions enabling or constraining customer centricity and value co-creation. At the micro level, they point to the importance of culture (the pattern of shared norms, values and beliefs), structure, processes and metrics (p.592).

It is the norms of actors within ecosystems, which we investigate further in this article and in the particular ecosystem of a high street. Norms are critical as part of the 'rules of the game' as well as the resources used by the ecosystem actors, the players' (Pop et al., p.595).

Norms are the behaviours and attitudes shared by most actors in the ecosystem (Vargo, Wiseland \& Akaka, 2015) and often referred to as tacitly held beliefs and actions. They establish a pattern of how specific things should/need to be done (Edvardsson et al., 2014). Norms can appear to be illogical but they persist as they are sensed as being right (Baron et 
al., 2018). Actors' adopt norms based on learning and from experiencing other actors' resource integration. The resultant norm may change an actors' attitude and behavior, which could result in institutional change or at least a need for it if many actors join together with a common set of norms (Edvardsson et al., 2014). Unlike rules, norms are not governed by sanctions (Baron et al., 2018) but can act as a set of learnings, which institutions can provide (Vargo \& Lusch, 2016).

Despite continued and growing academic interest in service ecosystems and the institutional norms, which shape the system, more empirical research is needed to gain a better understanding of the roles of actors in seemingly disparate categories and the processes through which these actors arrive at shared conceptions of problems and solutions (Wieland, Koskela-Huotari \& Vargo, 2016, p.222).

Using our investigation of shared norms, our research also sheds light on the nature of resource integration within the high street ecosystem. Specifically we reflect on the value and contribution of operant resources to value co-creation in this context. This addresses calls for more empirical work, which explores the dynamic nature of the complex institutional context, in which resource integration and value co-creation takes place (Wieland, KoskelaHuotari \& Vargo, 2016). Increasingly, understanding the nature and role of institutions and ecosystems is considered useful to, if not essential for, understanding value co-creation (Vargo \& Lusch, 2011).

\section{Method}

Research setting: the UK High Street

Town centres have always been important. They are places of creativity and enterprise and are places which 'allow us to share resources and services ... these long established places are our true eco-towns, resources whose health is critical to our sustainable future' (Scottish Government's External Advisory Group, 2013). In recent years, high streets have come under threat from a myriad of external factors. These include changing demographics, a technological revolution driving online shopping and an increasingly highly competitive landscape. The result has been a dramatic decline in the health of many UK high streets, visible through the increase in vacant space and job losses. Recent figures point to a net loss of 1,700 high street shops in the UK in 2018 and 40,000 jobs predicted to disappear by the end of the year (Centre for Retail Research, 2018). Despite these factors, the town centre 
remains an under researched context, in need of studies across a range of different consumer and business dimensions (Hart, Stachow \& Cadogan, 2013).

One of the widely reported barriers to successful regeneration is the existence of a complex and disparate network of actors involved in Town Centre strategy development (Grimsey 2018). These include Local Authority council leaders, retailers, community groups, citizens themselves, landlords, Business Improvement district leaders and public service organisations. Many have differing (and often conflicting) perspectives on what a successful high street should look like. Landlords for example, are criticised for making decisions, which prioritise return on investments over wider community benefits. Priorities and 'end goals' on economic and social regeneration are often not aligned. For example, an increase in leisure outlets i.e. bars, might have economic benefits, but can also result in increased crime and anti-social behaviour. In addition, town centres are increasingly being encouraged to develop as 'community hubs'. These are places 'where retail is a smaller part of a wider range of uses and activities and where green space, leisure, arts and culture and health and social care services combine with housing to create a space based on social and community interactions' (House of Commons Housing, Communities and Local Government Committee, 2019, p.21). Arguably, this has resulted in an even more complex eco-system with a wider network of disparate actors taking part in strategy development.

More recently, research has highlighted that one of the key characteristics of successful high street regeneration has been the ability of actors within the system to come together and develop a coherent business or marketing strategy. 'There is a need for all towns to develop plans that are business-like and focused on transforming the place into a complete community hub, while developing a unique selling proposition (USP)' (Grimsey, 2018, p.6). Crick, Chaudhry, \& Crick, (2016), adopting the 'business model canvas' offered by Osterwalder \& Pigneur (2010), suggest this involves identifying target segments and value propositions, developing strategies to manage customer relationships and defining channels to market, identifying specific activities and resources and finally monitoring costs and revenues. This approach resonates with the latest recommendations from the High streets and town centres in 2030 report, which recommend the creation of 'visionary strategies for high streets and town centres, which have the backing of the local community' (p.7). These need to be articulated in local plans, which represent living documents, regularly updated to 
capture and reflect changing trends (House of Commons Housing, Communities and Local Government Committee, 2019).

Given the characteristics outlined above, high streets present themselves as a natural ecosystem. They are complex and involve numerous actors, social forces, and co-creation and resource integration activities (Akaka \& Vargo, 2015).

Figure one illustrates the complex network of actors involved in the High Street ecosystem involved in our case study.

Figure 1. Key actors in our Retail High Street Ecosystem
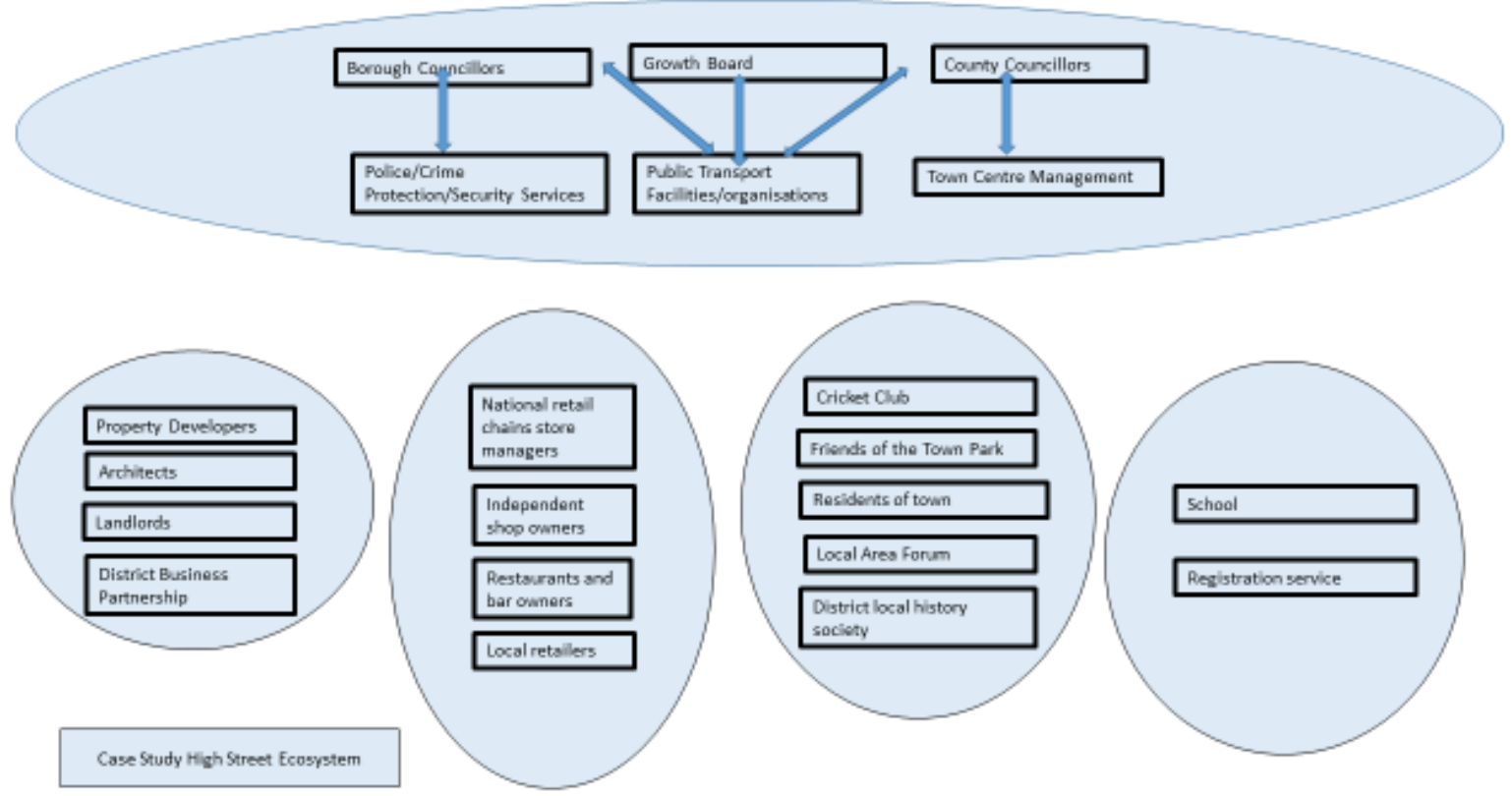

Successful regeneration is arguably dependent on effective value co-creation amongst actors in the system. To move this forward there needs to be in-depth understanding of the institutions i.e. the norms, rules, meanings, symbols and practices, which the connected actors share. Baron et al., (2018, p.139) recognise that 'the institution constructs are deeply interwoven and difficult to separate' so this study has been designed to explicitly explore the norms of stakeholders in a high street ecosystem town centre.

We have adopted a case study method (Eisenhardt \& Graebner, 2007; Yin 2014) incorporating multiple qualitative data sources to identify and illuminate the perspectives of the actors in the high street service eco-system. The study mirrors the approach followed by Baron et al., (2018) in their recent study of the UK foodshare ecosystem in that we wanted to identify the norms i.e the shared attitudes, of the actors within our town centre ecosystem. The use of a case study method allows us to focus on understanding the dynamics within this setting and 
combine several data collection methods, which enables the theory to be grounded through triangulation of the evidence (Eisenhardt, 1989). The adoption of a case approach also allowed us to highlight actors' perceptions of actions required to develop strategy in a UK high street context by accessing the views of multiple actors within the ecosystem and comparing voices of consumers, businesses, and public and private service providers The town itself (the case) has approximately 50,000 inhabitants, with an average mean age of 41 . The retail mix consists of 47 multiples chains and 65 independents with more bars and restaurants and charity shops than the national average. The town has a low unemployment rate and a relatively affluent population, defined as having median earnings by place of residence $20 \%$ ahead of the county average, and $15 \%$ above the national average (ONS Annual Population Survey, 2017). The town also has a reputation for a high quality, thriving and diverse retail, leisure and business sector but like so many towns across the UK, has an increasing number of vacant properties.

\section{Data collection and analysis}

Data was collected between July 2016 and October 2017, by an independent group of commissioners appointed by the Growth Board of the local council. Actors in the ecosystem took part in an extensive process of consultation designed to elicit their views about the future development of their high street and gather their perceptions of what would be required to develop a meaningful strategy. The actors were selected because of their 'information richness' (Morrow, 2005, p.259). They represent the views of a diverse spectrum of consumer groups, public and private sector officials and representatives from the voluntary sector. All hold different roles within the ecosystem but share a desire to improve the town centre offering and promote its unique selling points.

Table 1 provides details of the actors who participated in the study and the relevant data set. They were identified by the commissioners and the members of the Growth Board as key actors, representing the main interest groups and gatekeepers for the town centre (Morrow, 2005). The data gathered from the consultation process included results of an online and postcard survey amongst residents, generating 369 and 64 responses respectively, and faceto-face interviews with the key actors; the Growth Board, local retailers, property developers, representatives of the police and sporting associations. A range of key community groups took part in a series of structured public discussion forums and younger stakeholders from 
local schools expressed their views in a poster competition. The primary data was supplemented with archival data in the form of press releases and e-mails. In line with Baron et al., (2018, p. 145) call for research, we sought 'stories from key actors' in order that they could explain the institutional arrangements, which shape their attitudes and activities.

Table 1: Actors involved in the study and relevant data set

\begin{tabular}{|c|c|}
\hline Actor & Data Set \\
\hline Growth Board & $\begin{array}{l}\text { Participant observation in meetings (November 2016, April } 2017 \\
\text { and July 2017). Minutes of formal meetings and interviews with } \\
\text { members of growth board appointed to help commissioners } \\
\text { with data collection (July 2016-October 2017). Final report } \\
\text { published by growth board (October 2017). }\end{array}$ \\
\hline Borough Councillors & 3 interviews (March 2017) and minutes of meetings, emails. \\
\hline County Councillors. & Minutes of meetings (November 2016, April 2017, July 2017). \\
\hline $\begin{array}{l}\text { District Business } \\
\text { Partnership }\end{array}$ & $\begin{array}{l}\text { Key informant interviews (December 2016) and group } \\
\text { discussion. }\end{array}$ \\
\hline $\begin{array}{l}\text { Local Area Forum and } \\
\text { Friends of the Park } \\
\text { (community groups) }\end{array}$ & $\begin{array}{l}\text { Minutes of Community Group discussions (April } 2017 \text { and May } \\
\text { 2017). Follow up email correspondence. }\end{array}$ \\
\hline Police & 3 key informant interviews (May 2017). \\
\hline Cricket Club & Key informant interviews (May 2017). \\
\hline Local Schools & $\begin{array}{l}\text { Poster competition and } 2 \text { discussion groups (March and June } \\
\text { 2017). }\end{array}$ \\
\hline Registration Service & 1 Key informant interview (May 2018). \\
\hline $\begin{array}{l}\text { District Local History } \\
\text { Society }\end{array}$ & 2 key informant interviews (May 2017). \\
\hline Property Developers & Key informant interviews (March 2017). \\
\hline Local Retailers & $\begin{array}{l}2 \text { key informant interviews (March 2017) and social media } \\
\text { feeds. }\end{array}$ \\
\hline
\end{tabular}




\begin{tabular}{|l|l|}
\hline $\begin{array}{l}\text { National retail chains } \\
\text { and local store managers }\end{array}$ & $\begin{array}{l}\text { Social media feeds responding to press coverage of } \\
\text { commissioners work (December 2016-October 2017). }\end{array}$ \\
\hline $\begin{array}{l}\text { Owners of restaurant } \\
\text { and bars }\end{array}$ & $\begin{array}{l}\text { Social media feeds responding to press coverage of } \\
\text { commissioners work (December 2016-October 2017). } \\
2 \text { Key informant interviews (June 2017). }\end{array}$ \\
\hline Residents of Town & $\begin{array}{l}\text { Online and postcard survey (July 2017). Social media feeds } \\
\text { responding to press coverage of commissioners work } \\
\text { (December 2016-October 2017). }\end{array}$ \\
\hline
\end{tabular}

There are several considerations around collection and analysis of qualitative data. In addition to the requirement to demonstrate the research process and explain how the method used supports the data collected the analysis and the findings, there is a need to both understand and faithfully present the views of participants (Tosey, Lawley \& Meese, 2014). In a single case study, rich qualitative data is achieved by constructing a narrative using information from key participants together with other case data sources. The story is related back to theory to 'demonstrate the close connection between empirical evidence and emergent theory' (Eisenhardt and Graebner, 2007, p.29). We achieved this by carefully evaluating the 98 pages of field notes generated from the interviews, discussion forums, qualitative responses to the online resident survey and from additional reading of reports, minutes of meetings and social media feeds, immersing ourselves in the data to elicit information on the 'social situation under examination' (Suddaby, 2006, p.635). Guided by our definition of norms (Baron et al., 2018) we identified the common attitudes expressed within the corpus of data. Once the normative statements expressed by the actors was established, a thematic analysis approach (Braun, and Clarke, 2006) was applied, to identify and label the key norms.

The process of data analysis proposed by Miles and Huberman (1994) and coding techniques as detailed by Saldaña (2016) informed this study. Two researchers initially coded the data independently reading the data sources several times and extracting normative statements. This was followed by in-depth examination of the statements to cluster the data into normative categories. As the number of categories built up, cross-referencing was used to merge similar categories. Emerging themes and interpretations were discussed as part of the process to ensure triangulation of the various strands of data. This process was iterative. 


\section{Findings}

This study adopted an S-D Logic value co-creation perspective to explore collaborative strategy development in a High Street ecosystem. We began by identifying the myriad of actors active within a specific high street ecosystem, a town in the UK. This is captured in Figure 1. Drawing on insights from the actors in the system detailed in Table 1, the process of data analysis revealed the existence of seven shared norms framing perceptions of relevant strategy development. Using a value co-creation perspective, these norms form part of the glue that binds actors together. The seven normative categories are outlined below with illustrative statements from the data. Further extracts are detailed in Table 2.

Norm 1 : Equity/fairness (we should always try to create a level playing field for all businesses and citizens in our ecosystem)

Actors felt that it was important to ensure that members of the ecosystem should be treated fairly. There was a particular concern for fair treatment of different businesses irrespective of size, i.e. independents and multiple retailers and origin i.e. local retailers and national chains. This norm was vocalised particularly strongly by residents, as exemplified by this post on social media:

'We need to support our local independents and to give them incentives and encouragement to come here. The big chains are taking over $x$ and pricing out the independents' (resident view expressed on social media).

The notion of equity and fairness was also expressed in terms of facilities, access and retail provision. Actors were concerned about equality for those with disabilities and visitors of all ages and at different stages of their lifecycle.

'We need improved access for pushchairs and wheelchairs into shops and restaurants. Lots of mums and babies want to go for coffees or lunches in $x$ but don't feel welcomed if they bring a pram into most venues ' (community group discussion)

Norm 2: Balance of provision (we should make sure we have a mix of provision in our ecosystem)

This theme reflected a concern for getting an appropriate balance of provision. In particular, the concern to get a good mix of commercial and community based facilities as well as balance 
within the retail mix of types of business and services on offer. The mix should reflect the interests of a diverse population. Again, there were strong resident held norms on this.

'There is little cultural on offer. We need an arts centre possibly showing films on occasion, travelling exhibitions, events for children, local handicrafts and so on. There is a small theatre but it is far from the town centre. We have reached saturation point for restaurants and bars. Weekend evenings in the town centre have become as awful as in the city centre with people coming long distances to go from bar to bar. It should offer something for all ages' (resident survey).

Cultural diversity was also recognised as a priority for a thriving community:

'We should develop a cosmopolitan identity with a wide range of sustainable businesses and services that reflect residents' needs and values. That includes meeting the needs of not just the typical middle class middle aged white British families and working to include the youth, older adults, culturally diverse population, and those less advantaged. To include rather than isolate' (resident survey).

Norm 3: Access (we should make sure that everyone can access our ecosystem)

This featured strongly in the responses. Here actors were concerned that all decisions and actions should help to ensure that everyone could access the high street. Concerns related to two dimension of access. First, accessibility to the town centre itself i.e. provision of transport and second, access once in the centre.

'There should be better bus connections (higher frequency in the day and evening) with further out areas e.g $x, x$ and $x$ to encourage 'locals' to come in more, especially in the evening for drinks/dinner. As people in these areas need to take a taxi in to $x$, the temptation can often be to just head to the city centre instead' (stakeholder interview).

Resident comments focused on the access once in the town centre.

'Parking is a nightmare for those people wishing to just 'pop' in to shops and banks which I'm sure must be the majority of folk visiting it. The best way to make it more accessible would be to remove/restrict/ban the cars that bring the people in...!' (resident survey)

Norm 4: Best practice (the development of our ecosystem should be informed by best practice elsewhere) 
Actors felt that a key way to improve their own ecosystem would be to learn from the experience of others for example:

'Councillors should visit areas like $x$ and $x$ to see how they have more independent shops and restaurants which are more attractive for locals and visitors' (resident survey)

Within this norm was nested the expressed need that a coherent plan should be developed which built on good practice seen elsewhere:

'We need an overarching strategy that works everything together instead of piecemeal $-x$ is a great example of a place to match with' (stakeholder interview).

Norm 5: A sustainable, healthy environment (we should work to ensure that our environment is sustainable and healthy)

Again this norm underpinned many reflections on the future development of the High street. Actors shared the view that everything should be done to preserve and develop the green space and parkland in the ecosystem:

'We need to create a pleasant safer vibrant place to be so the locals will use it more and by maintaining it as such a place, then local people will use it more, why wouldn 't they?' (resident survey) and

'Greening the environment...more entertainment arts and creativity. We need less machinery and more of a natural village feel putting planet, people and local goods and services before landlords and big business (resident survey).

Further comments were around use of green spaces:

'We need to make more of the green spaces - think about the possibility of open air cinema in the park - outdoor art exhibitions (many local art appreciation groups/people), create a walking map of the central area to take in the history, consider 'architectural greenery, think about something that captures the different seasons of the year - blossom - summer -

Autumn in the same way the Xmas lights attract for winter' (stakeholder interview)

Norm 6: Point of Difference (we should take actions that reinforce the distinctive nature of our ecosystem)

Here the norm reflects a concern for making sure the place retains a distinctive identity. Although this is generally a 'marketing' subject, respondents demonstrate considerable expertise in the way they expressed this concern: 
'We need to create a brand' (resident survey) and 'We need a clear direction and strategy - it would be good to have a real draw that makes it stand out from the crowd. For example (many other possibilities are also available!) - it could aim to become a real destination for excellent food. Whilst there are a number of fairly good cafes and restaurants, there is nothing that would be classed as exceptional e.g. a Michelin starred restaurant or similar. Another option would be for music and events etc...' (resident survey).

Norm 7: Standards/professionalism (we should make sure all businesses in our ecosystem operate to certain standards)

The data revealed a shared view about the level of professionalism that should be applied by traders operating within the town. Although the specific detail might not be fully expressed in formal documentation, it was clear that many had an idea about what would be acceptable for the town. This referred to the presentation of buildings, shop fronts and window displays and levels of acceptable litter and crime in the ecosystem. For example one stakeholder perceived that :

'The calibre of shops needs lifting to $x$ and $x$ level to fit with visitors preferences' (stakeholder interview).

A consultancy group, who had been recruited to aid the strategy development commented that

'When benchmarking the exterior we look at the presentation of the premises, excluding the window display. The glass, frames facia, door pilasters and brick work are considered' clear rules on what is and is not acceptable, in the interest of the customer experience, needs to be communicated. Negatives considered to be 'excessive signage \& pavement signs' and reference to 'less desirable exteriors' retailers which were 'messy and drab' (consultancy report on retail provision).

The normative analysis also revealed evidence of operant resources at play in the high street ecosystem. Drawing on the classification suggested first by Arnould, Price \& Malshe, (2006) and subsequently by Baron \& Warnaby (2011) we found evidence of physical, cultural and social resources possessed by actors which, if harnessed effectively, have the potential to shape strategy implementation. These operant resources were identifiable within our normative themes. Two examples are discussed below to illustrate. 
Aligned to our equity and fairness norm, one respondent demonstrated cultural operant resources i.e. specialist knowledge of a scheme which had worked well in the past, to let local businesses use vacant properties for a trial period of a month.

I wanted to add my knowledge of an initiative which was held at the premises, which are now occupied by $x^{\prime}$ restaurant. These premises were formerly a shoe and ladies fashion shop. When the shop closed there was a period of vacancy, and a local woman, a green campaigner and community promoter was able to acquire these premises for a month in November' (member of local area forum).

Another respondent, aligned to our best practice norm offered specific advice about who to contact for best practice insights from within his own personal network of relationships i.e. social operant resources.

'I could put you in touch with the owner of $x$. He's a member of my gym. It would be worth talking to him to see what business decisions they are taking to balance the relationship between $x$ and the City? (Interview).

Many respondents illustrated that they had detailed knowledge of best practice taking place in high streets across the UK. It is also clear that many have innovative ideas about how the ecosystem might be developed. This is particularly evident from the comments associated with norm six above. Many actors demonstrated a relatively sophisticated 'marketing' vocabulary when discussing issues of positioning and branding. These are all operant resources, which exist within the eco-system, which could be effectively targeted and mobilised when developing future strategy.

INSERT TABLE 2

\section{Discussion and implications}

The importance of institutional theory in framing the S-D Logic perspective on value cocreation has already been widely recognised. Recent work has explored implications for innovation (Koskela-Huotari et al., 2016), dynamic capabilities (Nenonen, Gummerus \& Sklyar, 2018) actor participation (Wieland, Koskela-Huotari \& Vargo 2016) and resourceness (Koskela-Huotari \& Vargo, 2016). 
It is only recently that researchers working within the S-D logic value co-creation perspective, have started to unravel and explore different types and level of institutional influence. (Pop et al., 2018. Baron et al., (2018), looking at actors within the food share ecosystem recognise that 'the institutional constructs, norms, rules, meanings symbols and practices' are deeply interwoven and call for more empirical studies which try to unravel this complexity. For any detailed understanding, there is a need to clarify the distinctions between norms, rules, meanings, symbols, and practices (Baron et al., 2018, p.139). This is the major contribution of this study. Using insights from the myriad of actors participating in the enactment of value co-creation practices in the high street Service ecosystem, we have focused in on norms at play. We have identified seven normative categories, which appear to be sustaining institutional arrangements. These norms reflect agreement about equity and fairness, balance of provision, access, best practice, a sustainable, healthy environment, the need for a point of difference and standards and professionalism. These norms appear to be 'binding' disparate groups together and offer the potential to contribute to more sustainable strategy development. In this sense, our work provides much needed empirical support for the value of an institutional perspective underpinning value co-creation.

In a high street context, pressure is on actors to develop a 'community hub' solution incorporating a much wider range of community services and businesses. It is argued that retail can no longer be seen as the foundation of high street provision. Success requires bringing back housing, reimagining libraries as knowledge centres and connecting to heritage features within towns. The future sustainability of this particular ecosystem will depend on close co-operation and understanding between a much more diverse set of 'actors' than ever before. Having a detailed understanding of cultural differences (including norms) between these groups has never been more important for successful value co-creation. In addition, we believe that we have strengthened the connection between the institutional perspective and S-D Logic with our insights about the value of operant resources at play within the value cocreation process. Although the importance of operant resources have been well argued in the literature, we have illustrated the existence of specific types of operant resources, which align with our normative themes. Our view is that these stocks of resources could be mobilised to develop and implement a more sustainable strategy. This focus on the contribution of operant 
resources builds on more recent contributions in the field and represents a continuation of service-dominant logic's actor-to-actor perspective (Nenonen, Gummerus \& Sklyar, 2018).

According to Ng, Maull \& Smith (2011) one of the major 'customer centric' implications of the service ecosystem perspective is that it forces firms to recognise that because customers (actors) contribute available resources to the ecosystem, their competence should be recognised and understood. They argue that it is the role of the firm is to find ways to employ their competence in the service ecosystem. The same argument can be applied here. It is incumbent on the leaders of high street strategy development to find mechanisms to encourage and support actors to contribute their stock of operant resources to the cause.

\section{Implications for Place Management}

The crisis now facing the High Street means there is pressure on all actors to engage in more systematic strategic planning which brings together different groups with a range of skills sets. (Canhoto, et al., 2017) As evidenced in our research, there are valuable resources of actors with a range of skills within the eco-system, who are both willing and able to shape and action strategy. Town Centre managers must find ways of harnessing this resource. This may necessitate specific incentives to galvanise different parties. The voice of the consumer also needs to be elevated and incorporated into strategy making. Consumers make comparisons of other town centres as evidenced in both our research and other studies (Hart, Stachow \& Cadogan, 2013) and Town Centre management needs to be aware of which success factors are key to becoming a town centre of choice and addressing local issues such as access, parking and the retail mix. Involvement with representative groups as evidenced in this study will be intrinsic to successful future planning. The consultation process needs to be ongoing, open and transparent.

\section{Conclusion}

The aim of this research was to evaluate the role and contribution of a value co-creation perspective in exploring strategy making in the complex retail high street ecosystem. It draws on the evolving Service-Dominant Logic and its service ecosystems perspective, institutional theory and data from a depth case study of strategy development in a UK High Street 
An empirical case study has generated seven norms, which illustrate how practice is shaped through institutional work (Wieland, Koskela-Huotari \& Vargo, 2016). These norms reflect widespread agreement amongst actors about equity and fairness, balance of provision, access, best practice, a sustainable, healthy environment, the need for a point of difference and standards and professionalism. The norms identified in the study also provide evidence of valuable resource integration taking place between actors in the ecosystem. In particular the existence of extensive operant resources being activated by actors to co-create value within the ecosystem.

Our view is that this value co-creation perspective offers a welcome departure from the more traditional marketing approaches. First, it ensures that research captures deeper and more meaningful perceptions from a myriad of actors about strategy development. It enables this by gathering the views of all of the actors in the ecosystem rather than simply those involved in the buyer-seller exchange. Second, by unravelling the norms at play, rather than focusing on more surface content, insights can be used to shape the quality of future strategy development rather than used simply to understand past activity. In other words the generic norms identified here and shared by the multiple actors, can be used as a point of reference for more sustainable, decision-making moving forward. The high street ecosystem is notoriously complex, and arguably is becoming more so. It involves numerous actors, social forces, and co-creation and resource integration activities. Our study has illustrated how a value co-creation lens can help reconcile the views of the myriad of stakeholders within this ecosystem, with different problems, institutional arrangements, and visions of the future (Wieland, Koskela-Huotari \& Vargo, 2016).

\section{Limitations and further research}

Further research is needed in other high street locations, to examine whether these generic norms are prevalent in other similar settings. This could help to create a national picture and shape Government High Street policy interventions around high street regeneration. In addition, although our study focused on examining the 'norms' of the actors in the High Street ecosystem, further research could broaden this to include consideration of the full range of institutional arrangements such as symbols rules and practices operating within this ecosystem. 
Our normative analysis has drawn attention to the existence of operant resources, which could potentially be integrated into the strategy development process to help 'apply operant resources in a more effective manner' (Koskela-Huotari \& Vargo, 2016, p.166). More research is needed to identify exactly which operant resources can be applied to strategy development in the most effective manner. In the case of high street development, the cultural operant resources possessed by actors which are could be mobilised to enhance digital capability are likely to be the most valuable. Arguably, these could enhance the dynamic capability of the place and shape a clear point of difference for a particular high street.

\section{References}

Akaka, M.A. \& Vargo, S.L. (2015). Extending the Context of Service: From Encounters to Ecosystems. Journal of Services Marketing, 29 (6/7), 453-462.

Alves, H., Fernandes, C. \& Raposo, M. (2016). Value co creation: Concept and contexts of application and study. Journal of Business Research, 69, (5), 1626-1633.

Arnould, E. J., Price, L. L., \& Malshe, A. (2006). Toward a cultural resource-based theory of the customer. In R. F. Lusch \& S. L. Vargo (Eds.). The service-dominant logic of marketing: Dialog, debate and directions. (pp. 320-333). Armonk, NY: ME Sharpe.

Barney, J. (1991). Firm resources and sustained competitive advantage. Journal of Management, 17(1), 99-120.

Baron, S., Patterson, A., Maull, R. \& Warnaby, G. (2018). Feed People First: A Service Ecosystem Perspective on Innovative Food Waste Reduction. Journal of Service Research, 21, (1), 135-150.

Baron, S. \& Warnaby, G. (2011). Individual customers' use and integration of resources: Empirical findings and organizational implications in the context of value co-creation. Industrial Marketing Management, 40 (2), 211-218. 
Barrutia, J.M., Paredes, M.R. \& Echebarria, C. (2016.) Value co-creation in e-commerce contexts: does product type matter? European Journal of Marketing, 50 (3/4), 442-463.

Braun, V. \& Clarke, V. (2006). Using thematic analysis in psychology. Qualitative Research in Psychology, 3 (2), 77-101.

Canhto, A.I., Meadows, M., Ball, K., Daniel, E., Dibb, S. \& Spiller, K. (2017). The role of customer management capabilities in public-private partnerships. Journal of Strategic Marketing, 25 (5/6), 384-404.

Centre for Retail Research (2018) (online). Available at http//:www. http://www.retailresearch.org. (Accessed 5/07/2019).

Chandeler, J.D. \& Vargo, S.L. (2011). Contextualization and value-in-context: How context frames exchange. Marketing Theory, 11 (1), 35-49.

Collin-Lachaud, I. \& Reynolds, J. (2018). Who will be the retailers of tomorrow? Academy of Marketing Conference. July 2-5, 2018, Stirling, UK.

Crick, D., Chaudhry, S. \& Crick, J. M. (2016). Trading in a competitive environment: SouthAsian restaurants in the UK. Strategic Change, 25 (4), 371-382.

Damacena, C., Schmidt, S. \& Gauze, I.P.B. (2018). Service ecosystems: insights from a wedding. Management Research Review, 14 (12), 1395-1410.

Edvardsson, B., Kleinaltenkamp, M., Tronvoll, B. McHugh, P. \& Windahl, C. (2014). Institutional logics matter when coordinating resource integration. Marketing Theory, 14 (3), 291-309.

Eisenhardt, K. M. (1989). Building Theories from Case Study Research. Academy of Management Review, 14 (4), 532-550. 
Eisenhardt, K. M., \& Graebner. M.E. (2007). Theory building from cases: Opportunities and challenges. Academy of Management Journal, 50 (1), 25-32.

Finnegan, C., Runyan, R. C., Gonzalez-Padron, T. \& Hyun, J. (2016). Diversity and rigor trends in retailing research: assessment and guidelines. International Journal of Management Reviews, 18 (1), 51-68.

Fisk, R.P., Anderson, L., Bowen, D.E., Gruber,T., Ostrom, A.L., L., Patricio, L., Reynoso, J. \& Sebastiani, R. (2016). Billions of Impoverished People Deserve to Be better Served: A Call to Action for the Service research Community. Journal of Service Management, 27 (1), 43-55.

Frow, P., McColl-Kennedy, J. R., Hilton, T., Davidson, A., Adrian Payne. A., \& Brozovic, D. (2014). Value propositions: A service ecosystems perspective. Marketing Theory, 14 (3), 327351.

Galvagno, M. \& Dalli, D. (2014). Theory of value co-creation: a systematic literature review. Managing Service Quality, 24 (6), $643-683$.

Gao, G. Y., Murray, J. Y., Kotabe, M. \& Lu, J. (2010). A “strategy tripod" perspective on export behaviors: Evidence from domestic and foreign firms based in an emerging economy. Journal of International Business Studies, 41(3), 377-396.

Giddens, A. (1984). The constitution of society: Outline of the theory of structure. Berkeley: University of California Press.

Grimsey, W. (2018). The Grimsey Review 2 (online). Available at http://. www.vanishinghighstreet.com/wp-content/uploads/2018/07/GrimseyReview2.pdf. (Accessed 6/07/2018).

Grönroos, C. (2006). Adopting a service logic for marketing. Marketing Theory, 6(3), 317-333. 
Gummesson, E. (2008). Extending the service-dominant logic: from customer centricity to balanced centricity. Journal of the Academy of Marketing Science, 36 (1), 15-17.

Hart, C., Stachow, G. \& Cadogan, J.W. (2013). Conceptualising town centre image and the customer experience. Journal of Marketing Management, 29 (15/16), 1753-1781.

Hagberg, J., Sundstrom, M. \& Egels-Zandén, N. (2016). The digitalization of retailing: an exploratory framework, International Journal of Retail \& Distribution Management, 44 (7), 694-712.

Haase, M. \& Kleinaltenkamp, M. (2011). Property Rights Design and Market Process: Implications for Market Theory, Marketing Theory, and S-D Logic. Journal of Macromarketing, $31(2), 148-159$

Horbel, C., Popp, B., Woratschek, H. \& Wilson, B. (2016). How context shapes value cocreation: spectator experience of sport events. The Services Industries Journal 36 (11/12), 510-531.

House of Commons Housing, Communities and Local Government Committee (2019). High streets and town centres in 2030. (online). Available at https://www.parliament.uk/business/committees/committees-a-z/commonsselect/housing-communities-and-local-government-committee/inquiries/parliament2017/high-streets-and-town-centres-in-2030-inquiry-17-19/. (Accessed 20/02/2019).

Hunt, S. D. (2004). On the service-centered dominant logic of marketing. Journal of Marketing, $68(1), 21-22$.

Ind, N. \& Coates, N. (2013). The meanings of co- creation. European Business Review, 25 (1), 86-95

Johnson, G., Whittington, R. \& Scholes, K. (2011). Exploring Corporate Strategy. 9th Ed. Harlow: Pearson. 
Kolyperas, D. \& Sparks, L. (2018). Exploring value co creation in Fan Fests: the role of fans. Journal of Strategic Marketing, 26 (1), 71-84.

Koskela-Huotari, K. \& Vargo, S. L. (2016) Institutions as resource context, Journal of Service Theory and Practice, 26 (2), 163-178.

Kleinaltenkamp, M., Brodie, R.J., Frow, P., Hughes, T., Peters, L.D. \& Woratschek. H. (2012). Resource Integration. Marketing Theory 12 (2), 201-205.

Local Data Company (2018) Retail and Leisure Trends Report 2017/18. (online). Available at https://info.localdatacompany.com/download-Idcs-latest-retail-leisure-trends-report2017/18. (Accessed 15/01/2019)).

Lusch, R.F \& Vargo, S.L. (2014). The service-dominant logic of marketing: Dialog, debate and directions. Armonk, NY: ME Sharpe.

Lusch, R.F., Vargo, S.L. \& Tanniru, M. (2010). Service, value networks and learning. Journal of the Academy of Marketing Science, 38 (1), 19-31.

Mars, M., Bronstein, J. \& Lusch, R. (2012). The Value of a Metaphor: Organizations and Ecosystems'. Organizational Dynamics, 41, 271-89.

McColl-Kennedy, J., Vargo,S. L., Dagger, T.S., Sweeney, J.C. \& van Kasteren, Y. (2012). Health Care Customer Value Co-creation Practice Styles. Journal of Service Research, 15 (4), 370-389.

Miles, M.B \& Huberman, A. M. (1994). Qualitative Data Analysis. USA: Sage.

Morrow, S.L. (2005). Quality and Trustworthiness in Qualitative Research in Counseling Psychology. Journal of Counseling Psychology, 52 (2), 250-260. 
Nelson, R.R. \& Sampat, B.N (2001). Making Sense of Institutions as a factor shaping economic performance. Journal of Economic Behavior and Organization 44 (1), 31-54.

Nenonen, S., Gummerus, J., \& Sklyar, A. (2018). Game-changers: dynamic capabilities' influence on service ecosystems. Journal of Service Management, 29 (4), 569-592.

Ng, I., Maull, R., \& Smith, L. (2011). Embedding the new discipline of service science. In The science of service systems (pp. 13-35). Springer, Boston, MA.

North, D. C (1990). Institutions, institutional change, and economic performance. Cambridge: Cambridge University Press.

Osterwalder, A \& Pigneur, Y. (2010). Business Model Generation: A Handbook for Visionaries, Game Changers, and Challengers. London: John Wiley \& Son.

Office for National Statistics (2017). Annual Population Survey (online). Available at https://www.nomisweb.co.uk/articles/932.aspx. (Accessed 9/06/2019).

Pop, O. M., Leroi-Werelds, S., Roijakkers, N. \& Andreassen, T. W. (2018). Institutional types and institutional change in healthcare ecosystems. Journal of Service Management, 29 (4), 593-614.

Prahalad, C. K. \& Ramaswamy, V. (2004). Co-creation experiences: The next practice in value creation. Journal of Interactive Marketing, 18 (3), 5 -14.

Ramírez, R. (1999). Value co-production: intellectual origins and implications for practice and research. Strategic Management Journal, 20 (1), 49-65.

Ramaswamy, V. \& Ozcan, K. (2014). The co-creation paradigm. Redwood City: Stanford University Press. 
Ramaswarmy, V. \& Ozcan, K. (2018). What is co-creation? An interactional creation framework and its implications for value creation. Journal of Business Research, 84, 196-205.

Saldaña, J. (2016). The Coding Manuel for Qualitative Researchers. California: Sage.

Scott, W.R. (2008). Institutions and organisations: ideas and interests. Los Angeles: Sage.

Scott, W. R. (2014). Institutions and organizations .4th ed. Thousand Oaks, CA: Sage.

Scottish Government's External Advisory Group (2013) Report of the Community and Enterprise in Scotland's Town Centres (online).Available at https://beta.gov.scot/communityand-enterprise-in-scotlands-town-centres/community. (Accessed 20/07 2017).

Spohrer, J., Maglio, P.P. \& Bailey, J. (2007). Steps Toward a Science of Service Systems. Computer, 40 (1), 71-77.

Suddaby, R. (2006). From the Editors: What Grounded Theory is Not. Academy of Management Journal, 49 (4), 633-642.

Teece, D.J. (2014). The Foundations of Enterprise Performance: Dynamic and Ordinary Capabilities in an (Economic) Theory of Firms. Academy of Management Perspectives, Online. Available at https://doi.org/10.5465/amp.2013.0116. (Accessed 20/02/2019).

Tosey, P., Lawley, J. \& Meese, R. (2014). Eliciting Metaphor through Clean Language: An Innovation in Qualitative Research. British Journal of Management, 25, 629-646.

Vargo, S. L. \& Lusch, R. F. (2004). Evolving to a new dominant logic for marketing. Journal of Marketing, 68 (1), 1-17.

Vargo, S. L. \& Lusch, R. F. (2008). Service-dominant logic: continuing the evolution. Journal of the Academy of Marketing Science, 36 (1),1-10. 
Vargo, S.L. \& Lusch, R.F. (2011). It's all B2B ....and Beyond: Toward a Systems Perspective of the Market. Industrial Marketing Management, 40, (2), 181-87.

Vargo, S.L., Wieland, H. \& Akaka, M.A. (2015). Innovation through institutionalization: A service ecosystems perspective. Industrial Marketing Management, 44, 63-72.

Vargo, S. L. \& Lusch, R. F. (2016). Institutions and axioms: an extension and update of servicedominant logic. Journal of the Academy of Marketing Science, 44 (1), 5-23.

Vargo, S. L. \& Lusch, R. F. (2017). Service -dominant logic 2025. International Journal of Research in Marketing, 34, (1), 46-67.

Wieland, H., Koskela-Huotari, K. \& Vargo, S. (2016). Extending actor participation in value creation: an institutional view. Journal of Strategic Marketing, 24 (3/4), 210-226.

Wikström, S. (1996). The customer as co-producer. European Journal of Marketing, 30 (4), 619.

Witell, L., Anderson,L., Brodie, R.J., Colurcio, M., Edvardsson, B., Kristensson, P., LervikOlsen,L., Sebastiani, R. \& Andreassen, T.W. (2015). Exploring dualities of service innovation: implications for service research. Journal of Services Marketing, 29 (6/7), 436-441

Wrigley, N. \& Lambiri, D. (2015) (online) British High Streets: from Crisis to Recovery? A Comprehensive Review of the Evidence. (online). Available at https://eprints.soton.ac.uk/375492/ (Accessed 30/08/2017).

Yin, R. (2014) Case Study Research: Design and Methods. $5^{\text {th }}$ edition. London: Sage. 